\title{
PENGGUNAAN METODE CARD SORT UNTUK MENINGKATKAN KEAKTIFAN SISWA DALAM PEMBELAJARAN IPS KELAS VIII E SMP NEGERI 1 MAJALENGKA
}

\author{
Erma Nur Hanifah \\ Taat Wulandari \\ Jurusan Pendidikan IPS, FIS, UNY \\ Email: ermahanifah@uny.ac.id
}

\begin{abstract}
Abstrak
Tujuan penelitian ini untuk mengetahui: (1) upaya meningkatan keaktifan siswa dalam pembelajaran IPS di kelas VIII E SMP Negeri 1 Majalengka dengan menggunakan metode card sort; dan (2) peningkatan keaktifan siswa dalam pembelajaran IPS di kelasVIII E SMP Negeri 1 Majalengka dengan menggunakan metode card sort. Jenis penelitian ini yakni penelitian tindakan kelas (PTK) model Kemmis dan Taggart yang terdiri dari tahap perencanaan, perlakuan dan pengamatan, serta refleksi. Subjek penelitian ini adalah siswa kelas VIII E SMP Negeri 1 Majalengka yang berjumlah 40 siswa. Teknik pengumpulan data yang digunakan yaitu observasi siswa, angket siswa, dan wawancara siswa. Teknik analisis data dalam penelitian ini menggunakan analisis kualitatif. Hasil penelitian ini menunjukkan bahwa: (1) Upaya meningkatan keaktifan siswa dalam pembelajaran IPS di kelas VIII E SMP Negeri 1 Majalengka dengan menggunakan metode card sort dilakukan melalui beberapa upaya, seperti lebih menegaskan kepada siswa untuk mencari dan menggunakan informasi dari berbagai sumber, mengemukakan pendapat pada kegiatan presentasi, tidak hanya sekedar membaca saat presentasi dan siswa mengemukakan pendapat saat evaluasi pembelajaran. (2) Berdasarkan hasil triangulasi data diperoleh keaktifan siswa dapat dilihat dari rata-rata presentase seluruh indikator keaktifan siswa pada siklus I sebesar $65.67 \%$ menjadi $77.13 \%$ pada siklus II. Peningkatan telah memenuhi kriteria keberhasilan sebesar $=75 \%$, sehingga penelitian ini dapat dikatakan berhasil.
\end{abstract}

Kata kunci: metode card sort dan keaktifan siswa 


\begin{abstract}
The purpose of this research is to know: (1) effort to increase student activeness in IPS learning in class VIII E SMPNegeri 1 Majalengka by using card sort method; and (2) improvement of student activeness in IPS learning in class VIII E SMP Negeri 1 Majalengka by using card sort method. This type of research is classroom action research (PTK) Kemmis and Taggart model consisting of planning, treatment and observation, and reflection. The subjects of this study are students of class VIII E SMP Negeri 1 Majalengka which amounted to 40 students. Data collection techniques used are student observation, student questionnaires, and student interviews. Data analysis techniques in this study using qualitative analysis. The results of this study indicate that: (1) Efforts to increase student activeness in IPS learning in class VIII E SMP Negeri 1 Majalengka using card sort method done through several efforts, increasing presentation time and naming noncontributing students' names, and more opportunities for students to express their opinions during learning evaluations. (2) Based on the result of triangulation of data obtained from observation, questionnaires, and interviews there is increasing student activeness in social studies lesson. The improvement of students' activity can be seen from the average percentage of all student activity indicators in cycle I of $65.67 \%$ to $77.13 \%$ in cycle II. The increase has met the success criteria of $=75 \%$, so this research can be said successful.
\end{abstract}

Keywords: Card sort method and student activeness

\title{
Pendahuluan
}

Dewasa ini, suatu negara dikatakan sebagai negara maju salah satunya dapat dilihat dari segi kualitas pendidikan. Tilaar (2003: 193) mengemukakan negara maju seperti Amerika Serikat, Inggris, Kanada, Jerman, Perancis, Italia, dan Jepang sangat memperhatikan kualitas pendidikan negaranya. Pendidikan digunakan negara maju sebagai kekuatan dalam pelaksanaan pembangunan. Artinya, melalui pendidikan yang berkualitas dapat tercipta sumber daya manusia yang berkualitas agar dapat bersaing di tingkat internasional. 
Sekolah merupakan bagian dari lembaga pendidikan yang paling strategis untuk mewujudkan tujuan pendidikan nasional sebagaimana tertera dalam Undang-Undang Republik Indonesia Nomor 20 Tahun 2003. Oleh karena itu, kualitas sekolah harus menjadi perhatian tidak hanya bagi pemerintah tetapi seluruh warga sekolah termasuk guru. Tinggi dan rendahnya kualitas sekolah dapat diukur dari kualitas kegiatan pembelajaran di kelas yang dilaksanakan oleh guru.

Kegiatan pembelajaran yang berkualitas dapat diketahui dari interaksi antara guru dengan siswa yang menghasilkan perubahan-perubahan perilaku pada siswa terkait suatu materi pembelajaran termasuk pada materi pembelajaran IPS. Perubahan-perubahan perilaku siswa tersebut mengacu pada tujuan pembelajaran yang hendak dicapai. Salah satu tujuan dalam pembelajaran khususnya pembelajaran IPS yang dikemukakan Supardi (2011: 186-187) yaitu siswa diharapkan dapat mengembangkan kemampuan berpikir kritis dan inkuiri untuk dapat memahami, mengidentifikasi, menganalisis, serta memecahkan masalah-masalah sosial.

Berdasarkan hasil wawancara kepada salah satu guru mata pelajaran IPS kelas VIII SMP Negeri 1 Majalengka, guru memiliki kendala pada proses pembelajaran IPS di kelas yakni terkait kurangnya keaktifan siswa terutama di kelas VIII E. Kendala pada proses pembelajaran tersebut tidak terlepas dari faktor penyebab terjadinya masalah keaktifan siswa yang kurang. Guru mengatakan penyebab kurangnya keaktifan siswa kelas VIII E dikarenakan faktor pemilihan metode pembelajaran yang kurang tepat. Guru mengakui bahwa metode pembelajaran yang telah digunakan belum mampu menciptakan keaktifan siswa pada proses pembelajaran. 
Permasalahan yang telah dikemukakan harus segera diatasi. Kunci untuk mengatasi permasalahan tersebut terletak pada guru. Guru harus memilih metode yang tepat, terutama pemilihan metode pembelajaran yang mampu meningkatkan keaktifan siswa. Metode yang dapat digunakan untuk meningkatkan keaktifan siswa dalam pembelajaran IPS yaitu metode card sort. Berdasarkan hasil penelitian Istini (2012: 5) bahwa metode card sort berpengaruh terhadap keaktifan siswa. Hasil tersebut merupakan bukti empiris yang meyakinkan peneliti bahwa dengan menggunakan metode card sort dalam pembelajaran IPS dapat mengatasi masalah kurangnya keaktifan siswa kelas VIII E SMP Negeri 1 Majalengka.

Pada penggunaan metode card sort, siswa dibiasakan aktif bergerak mencari pasangan kartu yang sesuai kategorinya masingmasing (kategori tersebut dapat berupa judul maupun sub judul). Selain itu, siswa dibiasakan untuk mencari dan menggunakan informasi dari berbagai sumber saat mensortir kartu dan diskusi kelompok. Siswa juga dibiasakan ikut berkontribusi dalam kegiatan kelompok. Kemudian, siswa dibiasakan untuk berdiskusi sesuai dengan petunjuk guru. Terakhir, siswa diberikan kesempatan untuk mengemukakan pendapat saat kegiatan diskusi, presentasi kelompok, dan evaluasi pembelajaran. Kesimpulan dari uraian di atas yaitu setiap bagian-bagian dari kegiatan metode card sort membuat siswa terbiasa dan termotivasi untuk aktif secara fisik maupun non fisik dalam mengikuti proses pembelajaran. Pada akhirnya keaktifan siswa dapat diwujudkan melalui penggunaan metode card sort. Dengan demikian, peneliti tertarik untuk melakukan penelitian tentang "Penggunaan Metode Card Sort untuk Meningkatkan Keaktifan Siswa dalam Pembelajaran IPS Kelas VIII E SMP Negeri 1 Majalengka”. 


\section{Metode Card Sort}

Pada metode card sort, guru menggunakan kartu-kartu yang berisi materi pembelajaran tertentu. Sebagaimana pendapat dari Warsono dan Hariyanto (2013: 47) bahwa metode card sort merupakan pembelajaran yang menggunakan sebuah kartu indeks. Selain itu, Hisyam, Bermawy dan Sekar (2008: 50) mengemukakan metode card sort sebagai kegiatan kolaboratif yang bisa digunakan untuk mengajarkan konsep, karakteristik, klasifikasi, fakta tentang objek atau mereview informasi. Pendapat lain dari Asis dan Ika (2014: 167) yang menyatakan bahwa metode card sort bagian dari pembelajaran kooperatif yang mana peserta didik bergerak secara aktif dan dinamis mencari pasanganpasangan kartu. Adapun pendapat dari Elgood (1996: 44) yang mengemukakan metode card sort sebagai "exercise in which require that items should be set in order of importance or classified in some way".

Selain beberapa pendapat di atas, Piskurich, Peter, dan Brandon (2000: 53) mengemukakan bahwa metode card sort adalah "an activity in which teams learn content by identifying and sorting pieces of information into appropriate categories". Berdasarkan beberapa pendapat di atas, peneliti menggunakan pengertian metode card sort dari Piskurich, Peter, dan Brandon sebagai acuan dalam penelitian.

Dengan demikian dapat disimpulkan bahwa pengertian metode card sort yang peneliti kembangkan dari Piskurich, Peter, dan Brandon yaitu suatu aktivitas dimana siswa mempelajari materi dengan cara mengidentifikasi (mencari dan menggunakan informasi dari berbagai sumber) dan mensortir kartu kedalam kategori yang benar. 
Setiap metode pembelajaran memiliki langkah-langkah dalam penggunaannya, begitu pun dengan metode card sort. Walkin (2002: 19) mengemukakan how to play the game berikut ini: 1) The first player in each team's line turn over the top card, solved the problem, and attaches it in appropriate place on the chat, 2) When the first card is placed, the second player take and places the next card, 3) Play continues in the same way for the rest of the players until you call time at two minutes, 4) As you go over the correct answers, have each teamremove all incorrectly placed cards from the walkchart, 5) Have each team tally the remaining (correctly placed) cards, 6) Award one point for each correctly placed card. The team with the most points wins.

Selain itu, Silberman (2014: 169-170) menjelaskan langkahlangkah penggunaan metode card sort sebagai berikut: setiap siswa diberi kartu indeks yang berisi informasi atau contoh yang cocok dengan satu atau beberapa kategori. Siswa diminta untuk berkeliling ruangan dan mencari siswa lain yang memiliki kartu dengan kategori yang sama. Setelah siswa mencocokkan kartu dengan kategori yang sama, guru melakukan evaluasi pembelajaran.

Metode card sort memiliki kelebihan yaitu dapat membantu siswa untuk mempelajari informasi yang beragam dengan mudah. Sebagaimana pendapat yang dikemukakan oleh Piskurich, Peter, dan Brandon (2000: 47), bahwa "this method helps participants learn information that has multiple sections or parts and can be easily". Selain itu, metode card sort dapat menggairahkan siswa yang merasa penat karena terdapat gerakan fisik didalamnya (Silberman, 2014: 169). Pendapat lain dari Warsono dan Hariyanto (2013: 48) bahwa salah satu kelebihan metode card sort yakni dapat meningkatkan minat siswa terhadap pembelajaran. Adapun 
pendapat dari Nurochim (2013: 79) yang menyatakan kelebihan metode card sort dapat mengungkapkan daya ingat (recoll) terhadap materi pembelajaran yang telah dipelajari siswa. Selain kelebihan metode card sort terdapat pula kekurangan didalamnya. Menurut M. Hosnan (2014: 217) kekurangan metode card sort seperti: membutuhkan persiapan seperti pembuatan media berupa kartu-kartu dan suasana kelas menjadi gaduh. Kekurangan dalam metode card sort dapat diminimalisir dengan persiapan yang matang seperti pembuatan media, RPP, dan instrumen lain yang dibutuhkan, serta guru harus pandai dalam mengendalikan siswa agar dapat berjalan sesuai tujuan pembelajaran.

\section{Keaktifan Siswa}

Kegiatan pembelajaran yang berkualitas dapat diketahui dari interaksi multi arah antara guru dengan siswa maupun siswa dengan siswa lain yang menghasilkan perubahan-perubahan perilaku pada siswa terkait suatu materi pembelajaran. Dengan demikian, guru tidak dapat mendominasi melainkan harus menerapkan prinsip keaktifan siswa agar kegiatan pembelajaran di kelas lebih berkualitas. Jamil (2013: 100-101) berpendapat bahwa keaktifan siswa merupakan keterlibatan siswa pada pembelajaran baik secara abstrak maupun konkret.

Keaktifan siswa yang konkret biasanya berhubungan dengan kerja otot atau psikomotorik, seperti mendengar, menulis, membaca, menyanyi, menggambar, dan berlatih, sedangkan keaktifan siswa yang abstrak berupa kegiatan psikis, seperti menggunakan khazanah pengetahuan untuk memecahkan permasalahan, membandingkan konsep, menyimpulkan hasil pengamatan, dan berpikir tingkat tinggi. Selain itu, Oemar (2008: 137) memaparkan keaktifan siswa sebagai keterlibatan intelektual emosional siswa pada proses pembelajaran melalui asimilasi dan 
akomodasi kognitif untuk mengembangkanpengetahuan, tindakan, serta pengalaman langsung dalam upaya membentuk keterampilan (motorik, kognitif, dan sosial), penghayatan maupun internalisasi nilai-nilai dalam pembentukan sikap. Adapun pendapat dari Djamarah (2010: 370-371) yang menyatakan bahwa keaktifan siswa yaitu munculnya rasa ingin tahu, ketertarikan, dan minat siswa terhadap hal yang sedang dipelajari.

Indikator keaktifan dilihat dari kegiatan atau kesibukan apa yang dilakukan siswa dalam proses pembelajaran. Mohammad (2011: 157) berpendapat indikator keaktifan siswa antara lain, bertanya atau meminta penjelasan, mengemukakan gagasan, dan mendiskusikan gagasan orang lain dan gagasannya sendiri. Selain itu, Warsono dan Hariyanto (2013: 9) menyatakan indikator keaktifan siswa dilihat dari: 1) Belajar secara individual maupun kelompok untuk mempelajari dan menerapkan konsep, prinsip, dan hukum keilmuan, 2) Membentuk kelompok untuk memecahkan masalah, 3) Berpartisipasi aktif dalam menyelesaikan tugas yang diberikan guru, 4) Mampu bertanya, mengajukan pendapat, dan mengungkapkan kritik yang relevan, 5) Dapat melaksanakan pemikiran tingkat tinggi, seperti menganalisis, membuat kesimpulan, atau membuat prediksi, 6) Menjalin hubungan sosial sebagai bentuk interaksi pembelajaran, 7) Mampu menggunakan sumber belajar atau media belajar yang tersedia, dan 8) Berupaya menilai proses dan hasil belajarnya sendiri.

\section{Pembelajaran IPS}

Ilmu Pengetahuan Sosial adalah mata pelajaran yang kita jumpai mulai dari pendidikan dasar hingga menengah. Pengertian IPS di setiap jenjang pendidikan mempunyai perbedaan yang disesuaikan dengan perbedaan karakteristik siswa. Somantri 
(2001: 92) mengemukakan IPS sebagai penyederhanaan atau adaptasi dari disiplin ilmu-ilmu sosial dan humaniora, serta kegiatan dasar manusia yang diorganisasikan dan disajikan secara ilmiah dan pedagogis atau psikologis untuk tujuan pendidikan.

Mata pelajaran IPS di SMP memuat materi geografi, sejarah, ekonomi, dan sosiologi sesuai dengan Peraturan Menteri Pendidikan Nasional Nomor 22 Tahun 2006 tentang Standar Isi. Pembelajaran IPS dilakukan dengan pendekatan terpadu. Pembelajaran terpadu merupakan pembelajaran yang melibatkan atau mengaitkan berbagai bidang studi (Jamil, 2013: 252). Seperti yang telah kita ketahui, pembelajaran IPS merupakan integrasi dari berbagai materi dari cabang ilmu-ilmu sosial, seperti geografi, sejarah, ekonomi, dan sosiologi. Setiap mata pelajaran memiliki karakteristiknya masing-masing, termasuk IPS. Berikut uraian karakteristik mata pelajaran IPS khususnya di SMP/MTS yang dinyatakan oleh Trianto (2010: 175): a. Ilmu Pengetahuan Sosial merupakan gabungan dari unsur-unsur geografi, sejarah, ekonomi, hukum dan politik, kewarganegaraan, sosiologi, bahkan bidang humaniora, pendidikan, dan agama. b. Standar Kompetensi dan Kompetensi Dasar IPS berasal dari struktur keilmuan geografi, sejarah, ekonomi, dan sosiologi, yang dikemas sedemikian rupa sehingga menjadi pokok bahasan atau topik (tema) tertentu. c. Standar Kompetensi dan Kompetensi Dasar dapat menyangkut berbagai masalah sosial yang dirumuskan dengan pendekatan interdisipliner dan multidisipliner. d. Standar Kompetensi dan Kompetensi Dasar dapat menyangkut peristiwa dan perubahan kehidupan masyarakat dengan prinsip sebab akibat, kewilayahan, adaptasi dan pengelolaan lingkungan, struktur, proses dan masalah sosial serta upaya-upaya 
perjuangan hidup agar survive, seperti pemenuhan kebutuhan, kekuasaan, keadilan dan jaminan keamanan.

\section{Jenis Penelitian}

Jenis penelitian yang digunakan dalam penelitian ini adalah penelitian tindakan kelas (PTK). Zainal (2012: 98) mengemukakan bahwa penelitian tindakan kelas merupakan suatu proses penyelidikan ilmiah dalam bentuk refleksi diri yang melibatkan guru dalam situasi pendidikan tertentu dengan tujuan memperbaiki praktik pembelajaran. Adapun tujuan dilaksanakan penelitian ini yaitu untuk meningkatkan keaktifan siswa kelas VIII E SMP Negeri 1 Majalengka dalam pembelajaran IPS dengan menggunakan metode card sort. Selain itu, penelitian tindakan kelas dilakukan secara partisipatoris antara peneliti dan guru (Samsu, 2013: 41). Pada penelitian tindakan ini, peneliti bertindak sebagai observer dan guru bertindak sebagai pelaksana tindakan.

Desain penelitian tindakan kelas yang digunakan oleh peneliti adalah model spiral yang dikembangkan oleh Stephen Kemmis dan Robbin Mc Taggart. Menurut Epon (2014: 20) model spiral adalah suatu bentuk yang tidak berakhir pada suatu titik temu. Jadi dapat dikatakan bahwa model ini berlangsung dalam siklus atau tahapan yang berkelanjutan. Ada empat tahapan yang digunakan menurut model Kemmis dan Mc Taggart, meliputi tahap perencanaan (plan), tahap tindakan (act), tahap pengamatan (observe), tahap refleksi (reflect), kemudian tahap perencanaan kembali.

Tempat dan Waktu Penelitian

Penelitian ini akan dilaksanakan di kelas VIII E SMP Negeri 1 Majalengka, Kecamatan Majalengka, Kabupaten Majalengka, 
Provinsi Jawa Barat. Waktu penelitian ini berlangsung pada bulan Maret 2016.

Teknik Pengumpulan Data

a. Observasi

Observasi ini dilakukan dengan menggunakan lembar observasi untuk mengamati keaktifan siswa dalam pembelajaran IPS dengan menggunakan metode card sort.

b. Angket

Angket dalam penelitian ini digunakan untuk memperoleh data tentang keaktifan siswa dalam pembelajaran IPS dengan menggunakan metode card sort. Angket dalam penelitian ini diberikan langsung kepada siswa.

c. Wawancara

Dalam penelitian ini, peneliti menggunakan teknik wawancara terpimpin dimana pertanyaan-pertanyaan yang akan diajukan sudah melalui persiapan secara matang. Peneliti melakukan wawancara kepada informan, yaitu siswa.

Teknik Analisis Data

Teknik analisis data yang peneliti gunakan dalam penelitian tindakan kelas, yaitu teknik analisis data kualitatif. Menurut Miles dan Huberman dalam Sugiyono (2012: 334-343) tahapan analisis data kualitatif meliputi: Reduksi Data (Data Reduction), Penyajian Data (Data Display) dan Penarikan Kesimpulan atau Verifikasi (Conclusion Drawing).

Keabsahan Data

Menurut Sukmadinata (2013: 153) keabsahan menunjukkan bahwa data yang diperoleh dari hasil pengamatan adalah benar, dibandingkan dengan berbagai sumber, cara, dan waktu pun hasilnya hampir sama. Keabsahan data pada penelitian ini diperoleh melalui triangulasi teknik. Data dalam penelitian 
diperoleh dari data hasil observasi keaktifan siswa kemudian data tersebut dicek dengan data yang diperoleh dari angket, dan wawancara tentang keaktifan siswa.

Kriteria Keberhasilan Tindakan

Keberhasilan tindakan dalam penelitian ini mengacu pada kriteria keberhasilan minimal 75\%. Kriteria keberhasilan tersebut dijelaskan pada tabel di bawah ini:

Tabel 1

Kriteria Keberhasilan Tindakan

\begin{tabular}{|c|c|}
\hline Tingkat Penguasaan & Predikat \\
\hline $86-100 \%$ & Sangat Baik \\
\hline $76-85 \%$ & Baik \\
\hline $60-75 \%$ & Cukup \\
\hline $55-59 \%$ & Kurang \\
\hline$\leq 54 \%$ & Kurang Sekali \\
\hline
\end{tabular}

Sumber: Ngalim (2006: 103)

Berdasarkan tabel diatas, penelitian tindakan kelas ini dapat dikatakan berhasil apabila $=75 \%$ siswa kelas VIII E memiliki ratarata presentase seluruh indikator keaktifan siswa dalam pembelajaran IPS mencapai $=75 \%$. Peningkatan keaktifan siswa mengacu pada data hasil observasi, angket, dan wawancara tentang keaktifan siswa.

\section{Hasil Penelitian dan Pembahasan}

Hasil tindakan ini membuktikan bahwa siklus I sampai siklus II keaktifan siswa kelas VIII E SMP Negeri 1 Majalengka mengalami peningkatan dengan adanya penggunaan metode card sort. Hasil dari penelitian tindakan kelas ini sebagai berikut:

a. Siklus I

Siklus I dilaksanakan dalam dua kali pertemuan dengan waktu masing-masing pertemuan 3 x 40 menit. Selama 
JIPSINDO No. 1, Volume 5, Maret 2018

pelaksanaan tindakan, guru bertindak sebagai pelaksana tindakan sedangkan peneliti.

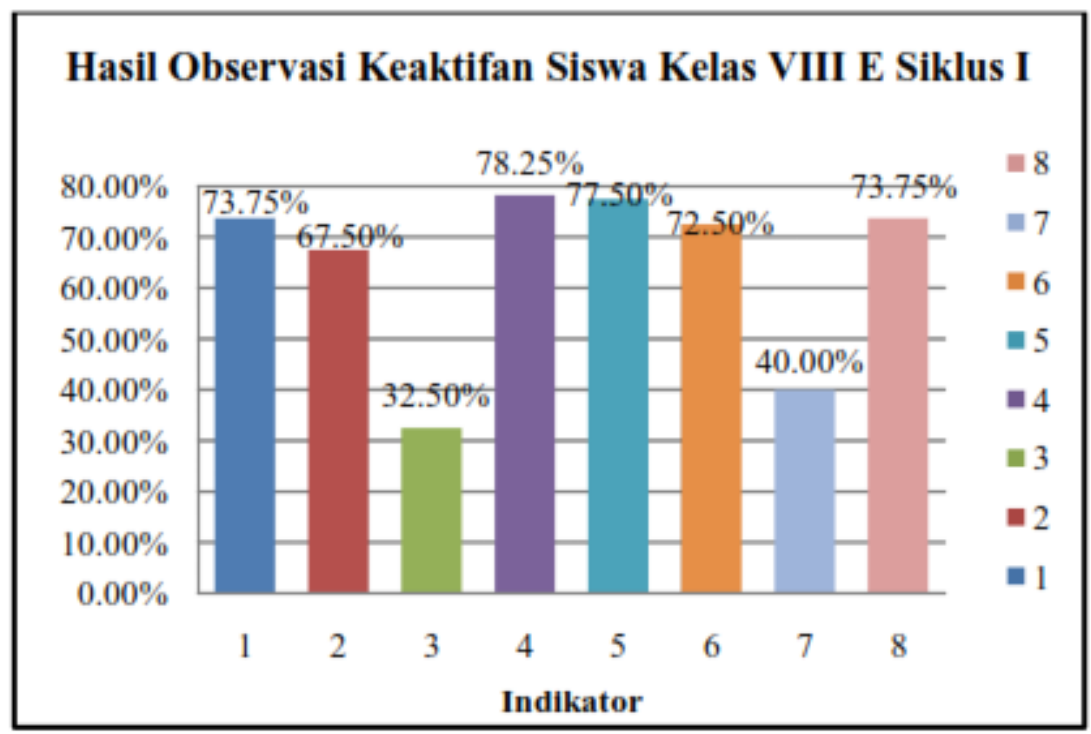

Gambar 1.

Grafik Presentase Hasil Observasi Keaktifan Siswa Siklus I

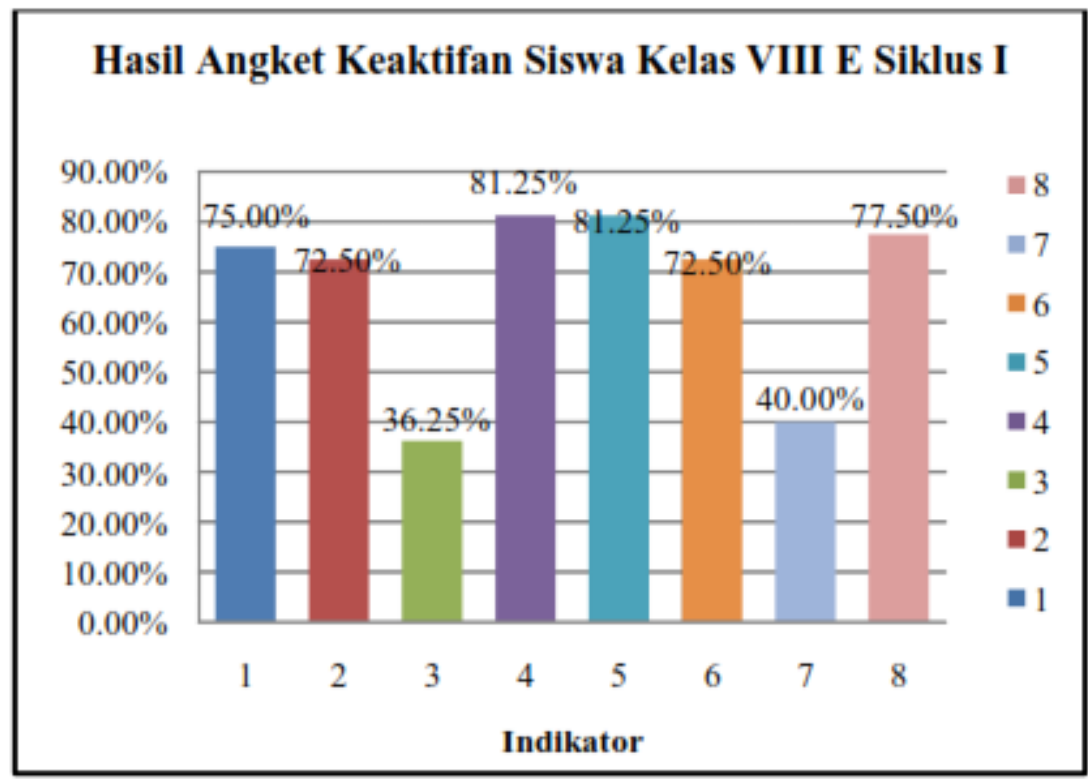

Gambar 2

Grafik Presentase Hasil Angket Keaktifan Siswa Siklus I 
b. Siklus II

Siklus II dilaksanakan dalam tiga kali pertemuan dengan waktu masing-masing pertemuan 3 x 40 menit. Selama pelaksanaan tindakan, guru bertindak sebagai pelaksana tindakan sedangkan peneliti bertindak sebagai observer dengan dibantu oleh dua teman peneliti. Siklus II diawali dengan tindakan yang meliputi perencanaan, perlakuan dan pengamatan, serta refleksi.

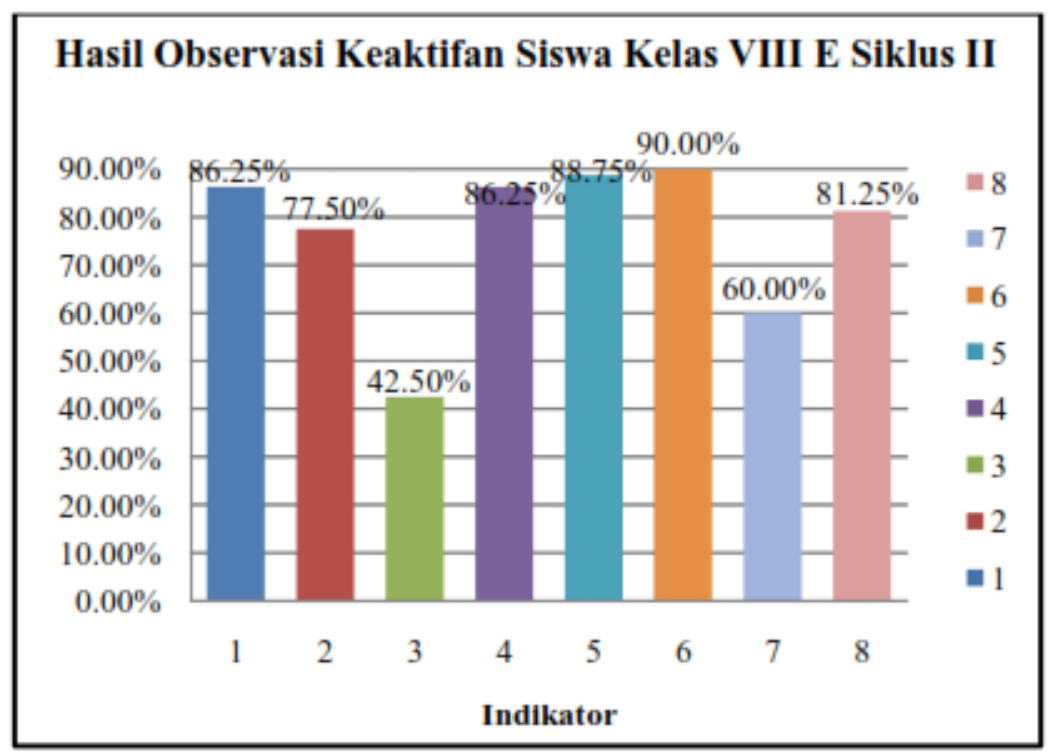

Gambar 3.

Grafik Presentase Hasil Observasi Keaktifan Siswa Siklus II

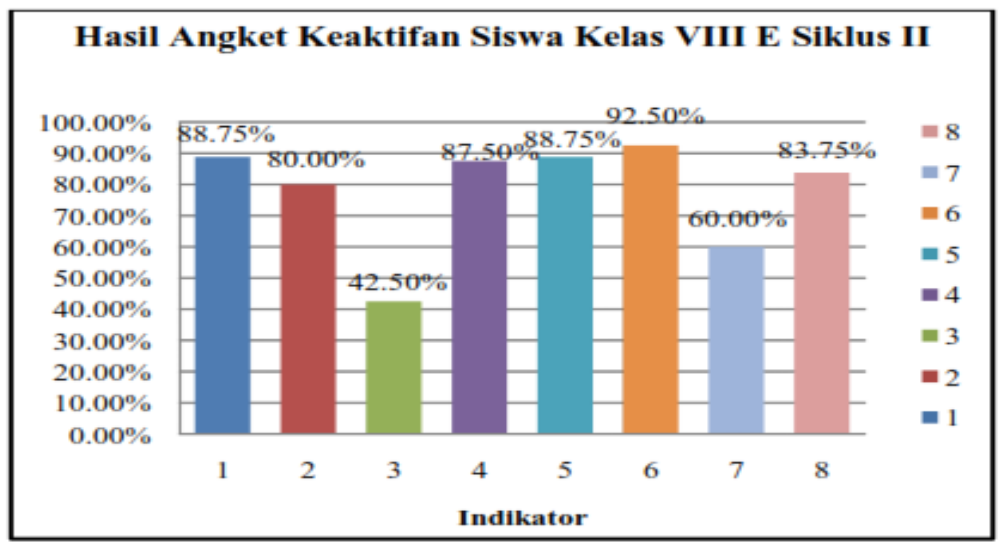

Gambar 4.

Grafik Presentase Hasil Angket Keaktifan Siswa Siklus II 


\section{Pembahasan}

Penggunaan metode card sort bertujuan untuk meningkatkan keaktifan siswa dalam pembelajaran IPS di kelas VIII E SMP Negeri 1 Majalengka. Penelitian ini dilakukan dalam 2 siklus. Siklus I dilaksanakan dalam 2 pertemuan dan siklus II dalam 3 pertemuan setiap hari Kamis pukul 07.00-09.00 WIB dan hari Sabtu pukul 10.10-12.10 WIB. Dalam penelitian tindakan ini, guru bertindak sebagai pelaksana tindakan dan peneliti sebagai observer.

Peneliti menggunakan data dari hasil observasi, angket, dan wawancara untuk memperoleh data tentang keaktifan siswa. Dari hasil pengamatan, keaktifan siswa kelas VIII E SMP Negeri 1 Majalengka pada siklus I masih rendah. Hasil tersebut disebabkan beberapa hal, seperti pada saat mensortir kartu, masih banyak siswa yang kurang tepat karena tidak mencari dan menggunakan informasi dari berbagai sumber dalam mensortir kartu. Selain itu pada saat diskusi kelompok dan pembuatan karya masih banyak siswa yang tidak ikut berkontribusi. Dalam diskusi kelompok pun masih banyak siswa yang pasif dalam mengemukakan pendapat dan berdiskusi di luar materi walaupun guru sudah memberi peringatan kepada siswa tersebut.

Berdasarkan hasil refleksi pada siklus I, terbukti adanya beberapa upaya perbaikan pada siklus II untuk mengatasi masalah rendahnya keaktifan siswa. Pada pertemuan I siklus II guru lebih menegaskan kepada siswa untuk mencari dan menggunakan informasi dari berbagai sumber terlebih dahulu dalam mensortir kartu. Guru pun memberi peringatan serta sanksi kepada siswa yang tidak ikut berkontribusi untuk mengemukakan pendapat pada kegiatan presentasi sehingga pada kegiatan diskusi kelompok seluruh siswa sudah dapat 
bekerjasama dengan baik dalam kelompoknya dan pada pertemuan II dan III siswa yang tidak ikut berkontribusi pada kegiatan diskusi dapat mengemukakan pendapatnya pada kegiatan presentasi.

Selain itu, diakhir pertemuan I guru menegaskan kepada siswa untuk mencari dan menggunakan materi dari sumber lain selain buku pegangan dan LKS serta tidak hanya sekedar membaca saat presentasi. Terlihat pada pertemuan II dan III sebagian besar kelompok sudah menambah materi dari sumber lain dan setiap siswa sudah lebih menguasai materi. Selanjutnya, pada pertemuan II dan III guru menambah waktu presentasi dan menyebutkan nama-nama siswa yang tidak ikut berkontribusi, sehingga siswa lebih banyak yang mengemukakan pendapatnya. Pada evaluasi pembelajaran setiap pertemuan siklus II, guru lebih banyak memberikan kesempatan kepada siswa sehingga siswa yang mengemukakan pendapatnya meningkat.

Dengan dilakukannya upaya perbaikan pada siklus II, penggunaan metode card sort menunjukkan adanya peningkatan pada keaktifan siswa kelas VIII E SMP Negeri 1 Majalengka. Peningkatan keaktifan siswa dapat dilihat dari rata-rata presentase seluruh indikator keaktifan siswa pada siklus I yaitu $65.67 \%$ menjadi $77.13 \%$ pada siklus II. Jadi dapat disimpulkan bahwa penggunaan metode card sort berhasil meningkatkan keaktifan siswa dalam pembelajaran IPS di kelas VIII E SMP Negeri 1 Majalengka.

\section{Simpulan}

Berdasarkan hasil dari penelitian tindakan yang telah dilakukan dengan judul "Penggunaan Metode Card Sort untuk Meningkatkan Keaktifan Siswa dalam Pembelajaran IPS Kelas VIII 
E SMP Negeri 1 Majalengka", diperoleh kesimpulan sebagai berikut:

1. Upaya meningkatan keaktifan siswa dalam pembelajaran IPS di kelas VIII E SMP Negeri 1 Majalengka dengan menggunakan metode card sort dilakukan melalui beberapa upaya, seperti lebih menegaskan kepada siswa untuk mencari dan menggunakan informasi dari berbagai sumber terlebih dahulu dalam mensortir kartu, memberi peringatan serta sanksi kepada siswa yang tidak ikut berkontribusi untuk mengemukakan pendapat pada kegiatan presentasi, menegaskan kepada siswa untuk mencari dan menggunakan materi dari sumber lain selain buku pegangan dan LKS serta tidak hanya sekedar membaca saat presentasi, menambah waktu presentasi dan menyebutkan nama-nama siswa yang tidak ikut berkontribusi, serta lebih banyak memberikan kesempatan kepada siswa untuk mengemukakan pendapat saat evaluasi pembelajaran.

2. Berdasarkan hasil triangulasi data yang diperoleh dari observasi, angket, dan wawancara terjadi peningkatan keaktifan siswa dalam pembelajaran IPS di kelas VIII E SMP Negeri 1 Majalengka dengan menggunakan metode card sort. Peningkatan keaktifan siswa dapat dilihat dari rata-rata presentase seluruh indikator keaktifan siswa pada siklus I yaitu $65.67 \%$ menjadi $77.13 \%$ pada siklus II. Jadi dapat disimpulkan bahwa penggunaan metode card sort berhasil meningkatkan keaktifan siswa dalam pembelajaran IPS di kelas VIII E SMP Negeri 1 Majalengka.

Pada dasarnya, penelitian ini dilakukan untuk mengetahui upaya dan hasil dari penggunaan metode card sort dalam meningkatkan keaktifan siswa pada pembelajaran IPS kelas VIII E 
SMP Negeri 1 Majalengka. Upaya dan hasil dari penggunaan metode card sort terbukti dapat meningkatkan keaktifan siswa kelas VIII E SMP Negeri 1 Majalengka dalam pembelajaran IPS. Oleh karena itu, apabila guru menggunakan metode card sort dalam pembelajaran IPS maka dapat meningkatkan keaktifan siswa.

\section{Daftar Pustaka}

Anas Sudijono. (2009). Pengantar Evaluasi Pendidikan. Jakarta: Rajawali Pers.

Asis Saefuddin dan Ika Berdiati. (2014). Pembelajaran Efektif. Bandung: PT Remaja Rosdakarya.

Azizah, Anindita Rahma. (2014). Penggunaan Metode Active Learning Tipe Card Sort untuk Meningkatkan Keaktifan dan Prestasi Belajar IPS Siswa Kelas IV SD Negeri Sendangsari. Jurnal Elektronik Basic Education, Vol. III, No. 13.

Bambang Warsita. (2008). Teknologi Pembelajaran: Landasan \& Aplikasinya. Jakarta: Rineka Cipta.

Djamarah, S. B. (2010). Guru dan Anak Didik dalam Interaksi Edukasi: Suatu Pendekatan Teoritik Psikologi. Jakarta: Rineka Cipta.

Elgood, C. (1996). Using Management Games. United Kingdom: Gower Publishing Ltd.

Epon Ningrum. (2014). Penelitian Tindakan Kelas: Panduan Praktis dan Contoh. Yogyakarta: Ombak.

Haris Herdiansyah. (2013). Wawancara, Observasi, dan Focus Group: Sebagai Instrumen Penggalian Data Kualitatif. Jakarta: Rajawali Pers.

Hisyam Zaini, Bermawy M. dan Sekar A. A. (2008). Strategi Pembelajaran Aktif. Yogyakarta: Pustaka Insan Madani.

Istini, Dhinar Dewi. (2012). Efektivitas Penggunaan Strategi Card Sort dan Index Card Match Terhadap Nilai Kognitif dan 
Keaktifan Siswa Pada Materi Fungi (Eksperimen pada siswa kelas X SMAN 2 Sukaharjo T. A.2011/2012). Naskah Publikasi Universitas Muhammadiyah Surakarta.

Jamil Suprihatiningrum. (2013). Strategi Pembelajaran: Teori dan Aplikasi. Yogyakarta: Ar-Ruzz Media.

M. Hosnan. (2014). Pendekatan Saintifik dan Kontekstual dalam Pembelajaran Abad 21. Jakarta: Ghalia Indonesia.

Marno dan M. Idris. (2012). Strategi dan Metode Pengajaran. Yogyakarta: Ar-Ruzz Media.

Martinis Yasmin. (2007). Kiat Membelajarkan Siswa. Jakarta: Gaung Persada Press.

Mohammad Jauhar. (2011). Implementasi PAIKEM dari Behavioristik sampai Konstruktivistik. Jakarta: Prestasi Pustakaraya.

Nana Sudjana. (2013). Penilaian Hasil Proses Belajar Mengajar. Bandung: PT Remaja Rosdakarya.

Ngalim Purwanto. (2006). Prinsip-prinsip dan Teknik Evaluasi Pengajaran. Bandung: Remaja Rosdakarya.

Nurochim. (2013). Perencanaan Pembelajaran Ilmu-ilmu Sosial. Jakarta: PT Raja Grafindo Persada.

Oemar Hamalik. (2005). Proses Belajar Mengajar. Jakarta: Bumi Aksara.

Aksara.

(2008). Kurikulum dan Pembelajaran. Jakarta: Bumi

Piskurich, G. M., Peter B., dan Brandon H. (2000). The ASTD Handbook of Training Design and Delivery. United States of America: Mc Graw-Hill Companies.

Samsu Somadayo. (2013). Penelitian Tindakan Kelas. Yogyakarta: Graha Ilmu.

Silberman, M. L. (2014). Active Learning: 101 Cara Belajar Siswa Aktif (Alih bahasa: Raisul Muttaqien). Bandung: Nuansa Cendekia. 
Erma Nur Hanifah, Taat Wulandari

Somantri, M. N. (2001). Menggagas Pembaharuan Pendidikan IPS. Bandung: Rosda.

Sugiyono. (2012). Metode Penelitian Kuantitatif, Kualitatif, dan Kombinasi (Mixed Methods). Bandung: Alfabeta.

Suharsimi Arikunto. (2006). Prosedur Penelitian Suatu Pendekatan Praktik. Jakarta: Rineka Cipta.

Jakarta: Bumi Aksara.

(2013). Dasar-dasar Evaluasi Pendidikan.

Sukmadinata, N. S. (2013). Metode Penelitian Pendidikan. Bandung: Remaja Rosdakarya.

Supardi. (2011). Dasar-dasar Ilmu Sosial. Yogyakarta: Ombak.

Tilaar, H. A. R. (2003). Kekuasaan dan Pendidikan: Suatu Tinjauan dari Perspektif Studi Kultural. Jakarta: Indonesia Tera.

Trianto. (2010). Model Pembelajaran Terpadu: Konsep,Strategi, dan Implementasinya dalam Kurikulum Tingkat Satuan Pendidikan (KTSP). Jakarta: PT Bumi Aksara.

Uno, H. B. dan Nurdin Mohamad. (2006). Orientasi Baru dalam Psikologi Pembelajaran. Jakarta: Bumi Aksara.

Walkin, L. (2002). Teaching and Learning in Further and Adult Education. United Kingdom: Nelson Thomas Ltd.

Warsono dan Hariyanto. (2013). Pembelajaran Aktif. Bandung: PT Remaja Rosdakarya.

Zainal Arifin. (2012). Penelitian Pendidikan: Metode dan Paradigma Baru. Bandung: PT Remaja Rosdakarya. 